\title{
Mechanistic Pathology and Therapy in the Medical Assayer of Marcello Malpighi
}

\author{
DOMENICO BERTOLONI MELI*
}

\begin{abstract}
A Medical Dispute around 1700
Around 1700 the Italian medical world witnessed a major controversy involving, among the others, Giovanni Girolamo Sbaraglia, Marcello Malpighi, and the young Giovanni Battista Morgagni, touching on a number of key features of the theory and practice of medicine. Sbaraglia defended empirical medicine and questioned the therapeutic significance of recent anatomical investigations, especially those of minute parts carried out with the microscope, and of the anatomy of animals and plants, as opposed to the human body. The last three-quarters of the seventeenth century had brought profound transformations in the understanding of the human body, yet their therapeutic significance was not obvious. Sbaraglia seemed to react to the lack of clear therapeutic advances and to what he perceived as the pointless excesses of anatomical investigations, most notably those by Malpighi.

The controversy involved quite a large number of texts, but the principal ones were Sbaraglia's opening salvo, De recentiorum medicorum studio dissertatio epistolaris ad amicum (dated 1687, but possibly from 1689), Malpighi's posthumous Risposta (1697), Sbaraglia's beautifully titled and rather profound reply, Oculorum et mentis vigiliae, ad distinguendum studium anatomicum, et ad praxin medicam dirigendam (1704), and Morgagni's two-letter rejoinder published under the pseudonyms of Orazio de Floriani and Luca Terranova, titled Epistola, qua plus centum, \& quinquaginta errores ostenduntur (1705). ${ }^{1}$ It seems plausible that this controversy may have contributed to reshaping the nature of eighteenth-century anatomical investigations, at least in Italy. A brief outline may help clarify my point. In 1661 Malpighi had published his first work, Epistolae de pulmonibus, where relying on rather interventionist techniques of microscopic investigation he had explored the structure of the lungs of frogs and other animals. Although in later publications Malpighi did investigate diseased states, his primary focus remained the investigation of structures. Exactly a century later, Morgagni's De sedibus, et causis morborum per anatomen indagatis (1761) dealt with anatomy without having recourse to the microscope, focusing on the location and causes of diseases in human cadavers, and in establishing a link with symptoms he had observed in his patients. Although Morgagni
\end{abstract}

(C) Domenico Bertoloni Meli 2007

* Professor Domenico Bertoloni Meli, Department of History and Philosophy of Science, Indiana University, Bloomington, Indiana 47405-2401, USA; e-mail: dbmelli@indiana.edu

Preliminary versions of this essay were presented at the Max-Planck-Institut for the History of Science in Berlin; the Center for the History of Medicine at
Indiana University, Bloomington; Stanford University; and the Scuola Normale Superiore, Pisa. I thank all those who offered comments and suggestions. I also thank for their helpful observations Marta Cavazza, Hal Cook, Christoph Lüthy, Carla Rita Palmerino, Massimo Scalabrini, Heinrich von Staden, and the anonymous referees of this journal.

${ }^{1}$ G B Morgagni, Opera postuma, Rome, Istituto di Storia della Medicina dell'Università di Roma, 1964, vol. 1, pp. 15-16. 


\section{Domenico Bertoloni Meli}

had offered major contributions to the investigation of anatomical structures with his monumental series Adversaria anatomica, in his key work De sedibus anatomy was joined with the investigation of disease. All these shifts are relevant to themes occurring in the disagreement with Sbaraglia and suggest that the dispute may have played a significant role in Italian medical circles.

My essay deals with the early stages of the controversy, especially Malpighi's reply to Sbaraglia. I believe this work to be of great interest for the light it sheds on how the anatomical findings of the seventeenth century, especially Malpighi's own, affected pathology and therapy. A few years ago Andrew Wear devoted an essay to the new anatomy and medical practice on the English scene, paying special attention to the relationships between patients and physicians. The issue of the relationships between new anatomy and medical practice is a large one and cannot be fully addressed here; doing so would require examining a broader set of texts, both theoretical and practical, such as the extensive body of medical consultations by Malpighi, Redi, and other mechanistic anatomists published in the eighteenth century. The special value of Malpighi's work is that it provides an extensive contemporary account, by one of the leading anatomists and physicians of his time, showing that while the pharmacopoeia had not changed, the rationale for the usage of many remedies, old and new, had undergone substantive transformation as a result of a new understanding of the normal operation of many organs and of their pathologies. As a result, at times standard remedies were applied in new circumstances not envisaged by traditional doctrines. ${ }^{2}$

Malpighi's work is extraordinarily rich and complex in more than one way. In addition to studying the relationships between new anatomy and therapy, I wish to offer a defence of the importance of styles of writing. Recent years have witnessed an increasing interest in narrative styles of scientific argument, especially with regard to experimental reports. My concerns here focus on a different aspect, namely the structure of a text and its significance, as well as the crucial role of coded messages embedded in a narrative style. Paying attention to these features can transform our reading of a text by shedding a different light on how it was conceived and received. Concern for the style to adopt in publications, especially those that are part of a controversy, was a common trait among scholars from

\footnotetext{
${ }^{2}$ A Wear, 'Medical practice in late seventeenth- and early eighteenth-century England: continuity and union', in R French and A Wear (eds), The medical revolution of the seventeenth century, Cambridge University Press, 1989, pp. 293-320; T M Brown, 'The College of Physicians and the acceptance of iatromechanism in England, 1665-1695', Bull. Hist. Med., 1970, 44: 12-30; idem, 'Physiology and the mechanical philosophy in mid-seventeenth century England', Bull. Hist. Med., 1977, 51: 25-54; Luigi Belloni provides useful background information in the introduction to M Malpighi, Opere scelte, Turin, UTET, 1967 (hereafter MOB); H J Cook, 'Physicians and the new philosophy: Henry Stubbe and the virtuosiphysicians', in French and Wear (eds), pp. 246-71; B B Kaplan, 'Divulging of useful truths in physick': the medical agenda of Robert Boyle, Baltimore, John Hopkins University Press, 1993; M Hunter, 'Boyle versus the Galenists: a suppressed critique of
}

seventeenth-century medical practice and its significance', Med. Hist., 1997, 41: 322-61; L Shapiro, 'The health of the body-machine? Or seventeenth century mechanism and the concept of health', Perspectives on Science, 2003, 11: 421-42; $\mathrm{G}$ Armillei, Consulti medici di vari professori spiegati con le migliori dottrine moderne, e co' le regole pi esatte della scienza meccanica, Venice, Giuseppe Corona, 1743-5, contains several consultations by Malpighi and other mechanistic anatomists; D Bertoloni Meli, 'Francesco Redi e Marcello Malpighi: ricerca anatomica e pratica medica', in W Bernardi and L Guerrini (eds), Francesco Redi: un protagonista della scienza moderna, Florence, Olschki, 1999, pp. 73-86; D Bertoloni Meli, 'The archivi and consulti of Marcello Malpighi: some preliminary reflections', in M Hunter (ed.), Archives of the scientific revolution, Woodbridge, Boydell Press, 1998, pp. 109-20. 
different epochs. Malpighi too was acutely aware of such issues and his correspondence often provides relevant instances. I shall argue that embedded in the style of Malpighi's Risposta to Sbaraglia is a profound philosophical and political message with deep implications on the medical and intellectual worlds of the time, especially the role of atomism in medicine. Before moving to that work, however, we need to discuss Malpighi's usage of Galileo's works and the peculiar status of his posthumous publications. ${ }^{3}$

\section{Malpighi and Galileo}

Malpighi was the sort of scholar who was more at home with his books, dissecting tools, and microscopes than in the midst of academic disputes. By contrast, his philosophical mentor, the philosopher and mathematician Giovanni Alfonso Borelli, was an intellectual with a striking "political" sense, who showed great confidence and a clear vision of the key issues at stake in a diatribe and was far from reluctant to impart his recommendations. Malpighi often relied on his senior colleague on a range of issues, from the usage of illustrations to the naming of opponents in print. Borelli was a source of inspiration for anatomical researches too, suggesting topics and interpretations in line with his mechanistic philosophy. The relationship between Borelli and Malpighi was deep from 1656, the year when they met on their arrival at Pisa University as professors of mathematics and medicine, respectively, to about 1668, when Borelli's continued paternalistic attitude and differences about anatomical matters and philosophical perspectives led Malpighi to break off their correspondence. At the same time, in 1668-9, Malpighi became associated with the Royal Society. The Society and its secretary, Henry Oldenburg, replaced Borelli in the role of guide and source of inspiration to Malpighi in intellectual matters, inducing him to work on the silkworm, for example. With Borelli, however, Malpighi had lost a skilful if overbearing philosophical guide and mentor on how to act in controversies. The Royal Society promoted a certain style of research and writing to which Malpighi adhered, but after 1668 Malpighi had to rely on his own resources and could not write to Oldenburg asking for advice as he was used to do with Borelli. ${ }^{4}$

It has long been known that Malpighi admired Galileo and found inspiration in his works, both as to themes and style. In 1659 Malpighi composed two dialogues among three personages, a Galenist physician, a chirurgus mechanicus or a surgeon whose manual skills were characterized as "mechanical", and a neutral observer. Unfortunately they are lost, but we have some information on them from Malpighi's own Vita or autobiography. They dealt with the nature of blood, purgation, nutrition, and the role of the faculties. In a revealing exchange, Malpighi submitted his own work to Borelli "so that he might guide

\footnotetext{
${ }^{3}$ The literature on this topic is vast. A useful collection of essays is in P Dear (ed.), The literary structure of scientific argument, Philadelphia, University of Pennsylvania Press, 1991. See also L Daston, 'Baconian facts, academic civility, and the prehistory of objectivity', Annals of Scholarship, 1991, 8: 337-63; D Rutkin, 'Celestial offerings: astrological motifs in the dedicatory letters of Kepler's Astronomia nova and Galileo's Sidereus nuncius', in W R Newman and A Grafton (eds), Secrets of nature: astrology and alchemy in early modern Europe, Cambridge, MA,
}

MIT Press, 2001, pp. 133-72. S Shapin, A social history of truth: civility and science in seventeenthcentury England, University of Chicago Press, 1994; M Ben-Chaim, 'Doctrine and use: Newton's "Gift of Preaching", ', Hist. Sci., 1998, 36: 269-98.

${ }^{4}$ D Bertoloni Meli, 'The new anatomy of Marcello Malpighi', and 'The posthumous dispute between Borelli and Malpighi', in D Bertoloni Meli (ed.), Marcello Malpighi: anatomist and physician, Florence, Olschki, 1997 (hereafter MAP), pp. 21-62, and 247-75. 


\section{Domenico Bertoloni Meli}

my still feeble steps by pointing out the smoother, safer path". The senior scholar replied urging Malpighi to take Galileo's Dialogue concerning the two chief world systems as a model not just in the structure, but also in matters of detail, such as the dignity of the personages. Malpighi's choice was Galilean in more ways than one. Of course, the structure of the work resembles Galileo's Dialogue and Discourses about two new sciences, but also the idea of having a chirurgus mechanicus refuting a learned Galenist physician suggested a link between social and intellectual matters not dissimilar from that we encounter in the opening of the Discourses, where Galileo described the Venice Arsenal as a suitable place to philosophize and praised the knowledge of the "proti" or skilled technicians working there. Galileo and Malpighi were keen to emphasize the importance of practice and observation over bookish learning. It is ironic that even Malpighi's philosophical mentor, the Galilean Borelli, found this stance excessive and suggested toning it down, because it looked improbable that an ignorant surgeon, presumably not university trained, could argue with a learned Galenist physician. ${ }^{5}$

In the 1660s, while he was at Messina, Malpighi used the contents of his Galilean dialogues in the Risposta to Michele Lipari, a text written against, quite appropriately, Galenist physicians and later published in Malpighi's Opera posthuma. Lipari was the young spokesperson for traditionalist circles at Messina. In this case too Malpighi submitted his work to Borelli for approval. On seeing a draft of the text, Borelli praised it and offered some stylistic advice on how to make it more effective by emphasizing the major points, this time urging Malpighi to learn from the style of Galileo's Assayer. Once again, Galileo was invoked as a literary model, but echoes of the Assayer can be found in specific passages too, as where Malpighi used the metaphor of the book of nature and of the need to understand the characters with which it is written. Here of course he was echoing the celebrated passage where Galileo had employed the metaphor of nature as a book whose characters are geometric figures like triangles and circles. In the same work Malpighi praised the telescope and the microscope, arguing that through the telescope Galileo had discovered more in astronomy than had been found in the previous millennia, and that the microscope too had revealed many mechanical contrivances in animals. In this way Malpighi was implicitly presenting himself as the Galileo of medicine, since he was the one who had made all the major anatomical findings through the microscope. ${ }^{6}$

Starting in 1661, Malpighi entered the public arena with the publication of his letters on the lungs, where he announced the discovery of their microstructure. His findings, including the anastomoses between arteries and veins and the alveoli or small air sacs in the lungs, constituted the first significant results of microscopic anatomy. Already in his first publications, Malpighi showed his remarkable skills with the microscope and with a wide range of techniques associated with microscopy, such as boiling,

\footnotetext{
${ }^{5}$ The correspondence of Marcello Malpighi, ed. $\mathrm{H}$ B Adelmann, 5 vols, Ithaca, Cornell University Press, 1975 (hereafter $M C A$ ), vol. 1, pp. 21-3, Borelli to Malpighi, 7 Nov. 1659. H B Adelmann, Marcello Malpighi and the evolution of embryology, Ithaca, Cornell University Press, 1966 (hereafter Adelmann), vol. 1, pp. 155-7, 166-7. D Bertoloni Meli, 'The new anatomy of Marcello Malpighi', op. cit., note 4 above. On the social status and training of surgeons in Italy at the time, see D Gentilcore, 'The organization of
}

medical practice in Malpighi's Italy', in $M A P$, pp. 75110 , on pp. $95-101$.

${ }^{6} M C A$, vol. 1, pp. 286-8, Borelli to Malpighi, 4 Nov. 1665 , on p. 287. See also $M C A$, vol. 1, p. 302, Borelli to Malpighi, 13 Feb. 1666; M Malpighi, Opera posthuma, Venice, ex Typographia Andreae Poleti, 1698, Risposta to Lipari, pp. 135-6; E Zinato, Il vero in maschera: Dialogismi galileiani, Naples, Liguori, 2003, p. 59; M Piccolino, Lo zufolo e la cicala, Turin, Bollati-Boringhieri, 2005, p. 141. 
scraping, and injecting body parts with fluids such as mercury and ink. If Robert Hooke's 1665 Micrographia was the most visually striking book of microscopy of its time, it was Malpighi who profoundly transformed anatomy by means of the microscope. Virtually all his publications show his virtuoso performance with that instrument. It seems impossible to escape the adroit analogy between, on the one hand, Galileo and the telescope and, on the other, Malpighi and the microscope. Both made of already available instruments remarkable research tools in astronomy and anatomy.

Lastly, in his edition of Malpighi's works, Luigi Belloni identified in Galileo's Assayer a source of Malpighi's research programme on sense perception. In paragraph 48 of the Assayer Galileo had outlined his theory of sensation, especially for taste, touch, and smell. Galileo argued that the speed and size of the particles of bodies would make a sensation pleasant or unpleasant: "Of these sensations, some are more pleasant to us and some less so, depending on the diversity of the figure of the tangible bodies, smooth or rough, acute or obtuse, hard or yielding." ${ }^{7}$ Galileo continued:

The minimi or tiny descending particles are received upon the upper portion of the tongue, where mixing with its moisture they penetrate its substance, and provide tastes, pleasant or unpleasant depending on the different ways in which they touch it, whether they are few or many, swifter or slower. The others that ascend, entering by our nostrils, strike some mammillae which are the instrument of smell, and here likewise their contacts and passages are received with our pleasure or annoyance, depending on their shapes being these or those, and their motions slow or swift, and the minimi being few or many. ${ }^{8}$

In 1665 Malpighi published a series of anatomical tracts on sense perception, including De lingua and De externo tactus organo. In those works he tried to relate the microstructure of the tongue, the skin, and the olfactory receptors in the nose to sense perception in a fashion close to Galileo's. Similar views were not uncommon in the atomistic tradition and in texts as diverse as Plato's Timaeus and, in the seventeenth century, in part IV of Descartes' Principia philosophiae. Malpighi referred explicitly to Timaeus, a major source for Galileo too. Belloni has argued that in those works Malpighi attempted to anchor philosophical doctrine to anatomical research by investigating through the microscope the structure and the nervous connections of those mammillae or papillae mentioned in the Assayer. More broadly, atomism was a lively subject of debate among seventeenth-century Italian intellectuals. ${ }^{9}$

\footnotetext{
${ }^{7}$ G Galilei, Opere, Florence, Barbera, 1890-1909, 20 vols in 21, ed. A Favaro (hereafter $G O F$ ), vol. 6, p. 349. Galileo talks also briefly of hearing, and merely mentions colours, leaving out sight. See also $M O B$, p. 141.

${ }^{8} G O F$, vol. 6, p. 349. I have amended the translation by S Drake and C D O'Malley in The controversy on the comets of 1618, Philadelphia, University of Pennsylvania Press, 1960 , pp. $310-1$, which contains some inaccuracies.

${ }^{9}$ MOB, pp. 181, 141. Plato, Timaeus, 61C-69A. In his edition of Plato's cosmology, New York,

Humanities Press, 1937, Liberal Arts Press, 1957, pp. 260-1, F M Cornford points to a distinction drawn by
}

Theophrastus between Democritus and Plato concerning the reality of sensations. At pp. 261-2 Cornford points to an inconsistency between Timaeus and Theaetetus. P Redondi, Galileo heretic (Princeton University Press, 1987, transl. Raymond Rosenthal), pp. 51-67; S Gómez López, Le passioni degli atomi. Montanari e Rossetti: una polemica tra galileiani, Florence, Olschki, 1997; idem, 'Marcello Malpighi and atomism', in MAP, pp. 175-89; M Bucciantini and M Torrini (eds), Geometria e atomismo nella scuola galileiana, Florence, Olschki, 1992; P Rossi, 'I punti di Zenone: una preistoria vichiana', Nuncius, 1988, 13 (2): 377-425, on pp. 382, 405-9, 417-20. 


\section{Domenico Bertoloni Meli}

Belloni was not the first to establish an explicit connection between Galileo and Malpighi. Already in a letter of 1666 the physician Giovanni Battista Capucci, a member of the Neapolitan Academy of Investigators, called Malpighi "Un $2^{\circ}$ Galileo"; Capucci was probably referring to the novelty of Malpighi's findings, but it is also significant that he was commenting on his theory of sensations. ${ }^{10}$

\section{Malpighi's Opera Posthuma}

Malpighi's Opera posthuma deserves special attention for its peculiar style. Throughout his life, Malpighi was quite consistent in being polite in print, avoiding name-calling, and treating with respect even those opinions he disagreed with. This behaviour was part of new attitudes to politeness developing in the seventeenth century and especially in the new scientific societies in response to the old style of academic disputations, which by then appeared sterile. $^{11}$

Matters changed with Malpighi's death. In order to appreciate this shift, one must remember that he was not caught unprepared by death, with a series of manuscripts he had not quite had time to bring to completion and put in print. Rather, his Opera posthuma was carefully engineered so that upon his death a substantial body of finished texts ready for publication was transmitted to the Royal Society. In the Risposta to Sbaraglia and in a letter to the secretary of the Royal Society, Richard Waller, Malpighi indicated his intention of sending the Risposta and other works after his death. Malpighi did not provide the reasons for this behaviour, but, judging from the style of his Opera posthuma, it seems safe to conclude that he wanted to take his gloves off and punch hard in order to set the record straight. Malpighi must have felt as if his own death would change the rules of the game, possibly because he could no longer be accused of seeking personal or financial advantage. Moreover, he made life difficult for his opponents, who found themselves in the awkward position of having to attack a dead person if they wanted to defend themselves. On page one of his reply, Sbaraglia noticed such a major difference in genere morali between Malpighi's Opera posthuma and the works published when he was alive, that he was led to question their authorship. In genere scientifico, however, he detected no difference; therefore he felt justified in proceeding with his rebuttal. ${ }^{12}$

The three main works of the Opera posthuma, the Vita a seipso scripta or autobiography, the Risposta to Lipari, and the Risposta to Sbaraglia, share a polemic tone absent from Malpighi's previous publications. The Vita is a huge work, over 100 folio pages, where Malpighi defended strenuously from attacks and criticism all his previous publications. His treatment of Borelli was especially interesting, since Borelli himself had voiced in his posthumous De motu animalium (1680-1) some criticisms of Malpighi's views. Borelli's work was posthumous because he happened to have died before having completed it. By contrast, Malpighi waited for fifteen years to follow Borelli to the afterworld in order to reciprocate the favour tenfold. His Vita is an extraordinary source for historians,

\footnotetext{
${ }^{10} M C A$, vol. 1, pp. 305-7, Capucci to Malpighi, Crotone, 4 April 1666, on p. 306.

${ }^{11}$ See, for example, Daston, op. cit., note 3 above. Shapin, op. cit., note 3 above.
}

\footnotetext{
${ }^{12}$ MCA, vol. 5, p. 1916, Malpighi to Waller, 6 Nov. 1693; $M O B$, p. 499; G G Sbaraglia, Oculorum et mentis vigiliae, Bologna, typis Petri Mariae Monti, 1704, pp. 1-2.
} 
because, whereas in previous publications Malpighi was often proceeding by allusions, there one finds spelt out with unusual candour and vigour all the key points and passages of a controversy, including page numbers of publications and extracts from private letters. In fact, one could say that the biographical material in his Vita provides a peculiar framework for a series of detailed anatomical studies on specific organs or problems, largely in response to attacks by his critics. ${ }^{13}$

We have seen that the Risposta to Lipari was a text dating from the mid-1660s, written by Malpighi while he was at Messina. Although in composing it he had used some of the material in his earlier Galilean dialogues, now the occasion for writing the text was a real controversy. Lastly, his reply to Sbaraglia is the object of my work and I shall focus on it in the rest of this paper.

\section{The Medical Assayer}

Sbaraglia was a colleague of Malpighi at Bologna University who was opposed to him on academic and probably also family grounds. In 1659 Malpighi's brother Bartolommeo had killed Giovanni Girolamo Sbaraglia's older brother, Tommaso, for reasons unrelated to academic affairs. As to intellectual matters, Sbaraglia's main line of attack was the belief that anatomy, especially of small animals and plants, was part of the study of nature and was of no use to the art of healing, but rather a distraction. He advocated instead an empirical approach and sought to defend his views with the help of a range of quotations from ancient and contemporary authors. Sbaraglia's attack against the utility of plant and insect anatomy was specifically addressed to Malpighi, who had published De bombyce, on the silkworm, in 1669 and the extensive Anatome plantarum in 1675 and 1679. Malpighi replied that those studies were not immediately aimed at finding therapies, but they sought to provide a deeper understanding of nature's operations in simpler organisms, in the hope of applying that knowledge to human anatomy and medicine at a later stage. ${ }^{14}$ Sbaraglia had his work printed surreptitiously, probably with a false imprint. The work was not for sale, but rather its author circulated it among a select number of friends and allies across Italy, thus retaining control of its readership. Initially it was difficult for Malpighi even to have access to the text, which he first saw only in a manuscript copy. ${ }^{15}$

Malpighi's reply is one of the most informative works on the medical scene at the end of the seventeenth century and has been rightly considered his scientific and philosophical will. ${ }^{16}$ It is a learned, profound, and especially passionate defence of rational medicine and the search for structural causes of disease, and of the importance of anatomy to the art of healing. This is the work whose style I wish to examine. I have always found its opening both striking and somewhat peculiar. While composing it, Malpighi had been a highly esteemed Fellow of the Royal Society for over twenty years: everything he wrote in those

\footnotetext{
${ }^{13}$ See D Bertoloni Meli, 'The posthumous dispute', op. cit., note 4 above.

${ }^{14}$ Zinato, op. cit., note 6 above, p. 50n9; Adelmann, vol. 1, p. 168; $M O B$, pp. 582-3, 596-602; on pp. 14-15 Belloni attributes the source of Malpighi's approach to Marco Aurelio Severino.
}

\footnotetext{
${ }^{15}$ Adelmann, vol. 1, pp. 556-7.

${ }^{16}$ M Cavazza, 'The uselessness of anatomy: Mini and Sbaraglia versus Malpighi', in $M A P$, pp. 129-45; A Marzolla, 'Alcune note su uno scritto apologetico di Marcello Malpighi', Annali delle Scuola Normale Superiore di Pisa. Classe di Lettere e Filosofia, 1990, 20: 169-84; $M O B$, p. 493.
} 


\section{Domenico Bertoloni Meli}

years up to his death was published by the Society, including the present piece. Moreover, in 1691 the newly elected Pope Innocent XII had called Malpighi to Rome as his personal archiater. As a result, the Bologna College of Physicians had elected him as one of its members. For the first time in its history someone who was not the descendant of three generations born in Bologna had gained election. Malpighi had become one of the most visible and respected physicians and anatomists in Christendom and his medical consultations were requested by the highest members of the clergy and aristocracy throughout Europe. Despite all this recognition and these achievements, this is how Malpighi starts his reply to Sbaraglia:

I have not and will never lend faith to that vulgar concept whereby some men, because of a concatenation of causes unknown to us, are subjected and condemned to a perpetual molestation and vexation, not only in domestic affairs, but also in literary ones, which are the most important. Yet, I find that concept evidently proved and realized in me, since as soon as I became doctor, I started seeing sarcastic writings against the doctrine that I was privately professing with the due respect toward everyone. I then read, during the course of time, books printed against me with ignominious titles and full of jokes. I heard sarcastic public lectures, especially on anatomy. In the academies discourses have been presented against my works that were pure satires. We have seen ignominious lunari and almanacs, and publicly defended conclusions that were pure libels. Lately we have seen a circular letter against my studies titled De recentiorum medicorum studio dissertatio epistolaris ad amicum, in which the author disparages and attacks rational medicine, and tries to prove the uselessness of anatomy, embracing empirical medicine. ${ }^{17}$

I have always been struck by the dichotomy between this passage, where Malpighi portrays himself as a victim, and the success story of his career. Possibly for this reason I had it at the back of my mind and it resonated when I reread a celebrated work by a scholar whose career had also been quite spectacular:

I have never been able to understand, your Excellency, how it comes about that every one of my studies which, in order to please or to be of service to others, I have seen fit to place before the public has occasioned in many a certain animus to detract, steal, or deprecate that modicum of esteem to which I thought I was entitled, if not for the work, at least for my intention. In my Starry Messenger were revealed many new and marvellous discoveries in the sky that ought to have pleased all lovers of true science. Yet it had scarcely been printed when men arose on all sides who envied the praises due to the discoveries thus made, and those were not lacking who merely to contradict what I said did not scruple to cast doubt upon things they had seen at will again and again with their own eyes. My Lord the Most Serene Grand Duke Cosimo II, of glorious memory, once ordered me to write my opinions on the causes of things floating or sinking in water, and in order to comply with this command I set down upon paper everything beyond the teachings of Archimedes that occurred to me, which perhaps is as much as may be truly said about the facts of this matter. And behold! immediately the whole press was filled with attacks upon my Discourse. My opinions were contradicted without the least regard for the fact that what I had set forth was supported and proved by geometrical demonstrations, and such is the strength of men's passions that they failed to notice that the contradiction of geometry is the bald denial of truth. How many men, and under what

${ }^{17}$ MOB, pp. 497-8. A paraphrase is in Adelmann, vol. 1, pp. 565-6; see also pp. 617-18.
Malpighi was still composing it in 1693, MCA, vol. 5, p. 1916, Malpighi to Waller, 6 Nov. 1693. 


\section{The Medical Assayer of Marcello Malpighi}

disguises, combated my Letters on the solar spots! The material contained therein, which should have opened to the mind's eye so much room for admirable speculation, was completely scorned and derided by many who either disbelieved it or little appreciated it; others, not wanting to agree with my conceptions, advanced ridiculous and impossible opinions against me; and some, conquered and convinced by my reasons, attempted to rob me of that glory which was mine by pretending not to have seen my writings and subsequently trying to make themselves the original discoverers of such impressive marvels. I say nothing of some of my private discussions, proofs, and propositions (many of them not published by me) having been seriously impugned or deprecated as worthless; yet even these have sometimes been chanced upon by others who have then exerted themselves with admirable adroitness to appropriate these honours as inventions of their own ingenuity. ${ }^{18}$

Obviously Galileo is the author of this passage from the Assayer, which continues with a long tirade against Simon Mayr for the plagiarism of the Geometric and military compass, thus covering virtually all Galileo's publications to that point. Galileo's Assayer was the product of an extensive collaborative effort of several members of the Lyncean Academy, who devoted great effort to matters of style and presentation. ${ }^{19}$ Appearing as a victim was a literary topos that reflected and resonated with Malpighi's feelings at the time. The tone of Malpighi's Vita a seipso scripta suggests that in the Risposta to Sbaraglia he was not just echoing Galileo's opening, but was also expressing his own feelings. The similarity between Galileo's Assayer, and Malpighi's Risposta are both quite striking and complex. Although Borelli was long dead, Malpighi remembered very well his advice in 1665 to use the Assayer as a model in controversies. Although Galileo sounded more self-confident, listed explicitly his own works, and included plagiarism among the long list of injustices he had to suffer, the opening litanies of vexations are clearly analogous. The analogies extend well beyond the two works' openings and concern their structure, circumstances of composition, philosophical outlook and contents. Although Malpighi was not alone in having adopted Galileo's style, his Risposta had such profound and wide-ranging Galilean implications to set it apart from other contemporary works that relied on this or that Galilean motive. $^{20}$

Much like Galileo in the Assayer, Malpighi found himself attacked in a work of dubious authorship: the name on the title page of the Libra astronomica, Lothario Sarsi, was that of an alleged pupil of the prominent Jesuit mathematician Orazio Grassi, who was its true author. Sbaraglia's De recentiorum medicorum studio appeared anonymously with the imprint Göttingen, 1687. Galileo's title referred to the goldsmith's balance and underscored his intention to assay and criticize the entire text with the utmost care. He reproduced Sarsi-Grassi's Libra paragraph by paragraph and dissected each of them relentlessly, arguing that this would give him an advantage over Sarsi-Grassi's way of selecting this or that passage at his convenience, but omitting the most powerful ones. ${ }^{21}$ Malpighi also adopted this strategy; he too chose to reproduce his opponent's text fully, but

\footnotetext{
${ }^{18}$ GOF, vol. 6, pp. 213-14; The controversy of the comets of 1618, op. cit., note 8 above, pp. 163-4.

${ }^{19} \mathrm{D}$ Freedberg, The eye of the Lynx: Galileo, his friends, and the beginnings of modern natural history, University of Chicago Press, 2002, pp. 57-8, 74-5, 140-7.
}

\footnotetext{
${ }^{20}$ On Galileo's Assayer, see A Battistini, Galileo e $i$ Gesuiti, Milan, Vita e pensiero, 2000, pp. 134-64; Piccolino, op. cit., note 6 above, pp. 141, 151, 158 .

${ }^{21}$ GOF, vol. 6, p. 372.
} 


\section{Domenico Bertoloni Meli}

whereas Galileo had divided it in sections preceding the relevant portion of his response, Malpighi reprinted it as a whole and referred to it paragraph by paragraph as he went along. The structure and line of reasoning of the Assayer and Malpighi's Risposta is thus heavily dictated by the texts criticized. Moreover, both the Assayer and the Risposta were part of a long series of exchanges over several years involving other scholars as well, such as Galileo's friend Mario Guiducci. In Malpighi's case the controversy extended into the eighteenth century and involved physicians and anatomists such as Giovanni Paolo Ferrari at Parma, Johannes Bohn at Leipzig, and the young Morgagni. ${ }^{22}$

In addition to using Galileo's Assayer as a template for his own reply to Sbaraglia, Malpighi relied on some of Galileo's most famous doctrines expressed in that work and applied them to medical matters. Sbaraglia had quoted De decretis Hippocratis et Platonis, where in comparing Plato and Hippocrates, Galen had stated that whether the parts of fire have a pyramidal figure or those of the earth a cubical one is of no use to the art of healing. The text alluded to was Timaeus, one that was well known to Malpighi and Galileo, where the four elements were given geometric shapes appropriate to their properties. Quite remarkably for a physician/anatomist involved in a medical dispute, Malpighi sided with Plato against both Hippocrates and Galen in claiming that the elements do not act because of their being hot, cold, moist, or dry, but because of their motion and shape. This extraordinary passage continues:

Therefore, that heating in the fire is an effect of its figure and motion, and is, among the many effects fire produces, perhaps the least significant. Rather it has no existence but in the sensory organs of touch of the animals, being outside the passions of the animal, motion and insinuation. And since in our body fire, air, water and earth operate not with their sole qualities (which are also controversial), but with their figure and motion, by assigning those properties [of figure and motion] Plato does not bring a superfluous notion to the physician, but rather Hippocrates is in defect in neglecting them. ${ }^{23}$

It is not difficult to identify in this passage an application to medicine of Galileo's so-called doctrine of primary and secondary qualities of the Assayer, one derived from Plato as well as from the atomists. Much like Galileo, Malpighi distinguished between properties like figure and motion, existing independently of our senses, and qualities that reside only in our senses, such as heat and moisture. Air, for example, does not act in us because it is moist and hot, but rather because it consists of spiral particles whose motion and compression cause healthy and diseased states. Here Malpighi was expanding on

\footnotetext{
${ }^{22}$ A brief account of the dispute is in A Zeno, 'Relazione della Controversia', Giornale de' Letterati d'Italia, 1710, 4: 263-292. See also C Pighetti, 'Un dialogo di Domenico Guglielmini restituito alla critica da Giambattista Morgagni', in V Cappelletti and F di Trocchio (eds), De sedibus et causis. Morgagni nel centenario, Rome, Istituto della Enciclopedia Italiana, 1986, pp. 125-33; A Dini, 'La difesa della "medicina razionale” e il giovane Morgagni', in ibid., pp. 147-54. Malpighi had followed the Assayer in style and contents in his reply to Lipari too; Zinato, op. cit., note 6 above, pp. 45-64.
}

\footnotetext{
${ }^{23}$ Galen, Opera, Kühn, vol. 5, pp. 667-71; $M O B$, p. 615; G Giglioni, 'The machines of the body and the operations of the soul in Marcello Malpighi's anatomy', in $M A P$, pp. 149-74. M L Altieri Biagi and B Basile (eds), Scienziati del Seicento, Milano-Napoli, Ricciardi, 1980, p. 1169, identifies Galileo's distinction between primary and secondary qualities as Malpighi's source. Adelmann, vol. 1, p. 585, does not report or comment on this passage. Surprisingly, Belloni too did not identify Galileo's Assayer as Malpighi's source for the structure and style of the Risposta to Sbaraglia.
} 


\section{The Medical Assayer of Marcello Malpighi}

ancient doctrines on the basis of recent seventeenth-century developments. ${ }^{24}$ Thus Malpighi proposed a subversion of traditional medicine and its reliance on qualities like hot and cold, or dry and moist. Since the standard understanding of the body's operations and a huge portion of traditional therapeutics relied on those notions, his mechanical reinterpretation was quite radical.

Malpighi mentioned Galileo only once in his Risposta, praising his modesty and listing him as the first among the Moderns. In addition, while providing a panorama of the achievements of seventeenth-century medicine and anatomy, he mentioned several scholars whom he considered to have worked on his wavelength, such as Borelli. On one occasion Malpighi mentioned L'homme by Descartes, but Cartesian themes figure quite prominently in the Risposta even implicitly, as when Malpighi described the structure of the brain as consisting of pierced threads that are more or less taut. Throughout his work Malpighi adopted a radical mechanicism; he talked of animals as machines or automata and argued that the eye works like a camera obscura and the machines in our body consist of ropes, beams, levers, cloths, flowing fluids, cisterns, and filters. ${ }^{25}$

We would be mistaken in thinking that Malpighi followed Galileo blindly, both because Malpighi had his own agenda, and because the Assayer is a complex text where Galileo found himself in the awkward position for a defender of the sensate esperienze of making claims about things he had not seen. When the 1618 comet at the centre of the dispute appeared, Galileo was bedridden and unable to make any observations. Probably this is the reason why he advocated a form of learned scepticism in the famous parable of the cicada. A man endowed with extraordinary curiosity and a penetrating mind, but living in great isolation, raised many birds because he enjoyed their songs. One day on hearing a delicate sound outside his dwelling, he assumed it to come from a bird, but was surprised to find a boy playing a wind instrument. He later discovered string instruments, screeching hinges, half filled goblets, and many types of insects. Generally they produced noise with the beating of their wings, but the cicada could be heard even after its wings had been stopped. Alas, in pushing his curiosity too far, the investigator killed it. Galileo wished to emphasize nature's bounty as a way to justify his ignorance about the comet. There was no question that sound, however, was always produced by air vibrations, whereas the nature of comets was rather more mysterious. ${ }^{26}$

In his work on kidneys in the 1660s, Malpighi had adopted an approach similar to Galileo's parable of the cicada. While firmly believing that the kidneys operate mechanically, he had argued: "Nature is very fecund in her ways of operating, machines unknown

\footnotetext{
${ }^{24}$ Galen referred to the atomistic doctrine of primary and secondary qualities in De elementis ex Hippocrate, I, 2, in Galen, Opera, Kühn, vol. 1, pp. 417-18. Malpighi may have had a source derived from Boyle in mind here; see $A$ defence of the doctrine touching the spring and weight of the air, in Robert Boyle, Works, ed. M Hunter and E B Davis, 14 vols, London, and Brookfield, VT, Pickering \& Chatto, 1999-2000, vol. 3, p. 84. According to $\mathrm{O} \mathrm{Gal}$, Meanest foundations and nobler superstructures, Dordrecht, Kluwer, 2002, p. 127, the relevant passage was due to Hooke.
}

\footnotetext{
${ }^{25}$ MOB, pp. 508, 512, 549, 556, 589. The role of Cartesian themes and images in Malpighi's Risposta would deserve a special study. P Galluzzi, 'G.A. Borelli dal Cimento agli Investiganti', in F Lomonaco and M Torrini (eds), Galileo e Napoli, Napoli, Guida, 1987, pp. 339-55, on p. 341-2; F Duchesneau, Les modèles du vivant de Descartes à Leibniz, Paris, Vrin, 1998, p. 202.

${ }^{26}$ Different but in my view not entirely incompatible views on the parable have been put forward by M Biagioli, and by M H Shank, Early Science and Medicine, 1996, 1: 87-92, and 141-5.
} 


\section{Domenico Bertoloni Meli}

to us will be found, which may even be beyond our grasp." ${ }^{27}$ In the Risposta to Sbaraglia, however, Malpighi was in no mood to stress that Nature's ways of operating may be beyond our grasp; rather, he forcefully stated that she "operates by an ever uniform necessity" and the mind can reach even where the eye cannot. ${ }^{28}$

There is another difference in style between the two texts concerning textual authority versus the authority of nature. In the Assayer Galileo chastised Sarsi-Grassi's tendency to defend his views by having recourse to celebrated authors. This is the well-known passage where Galileo continues claiming that the language of nature is mathematical and consists of geometrical figures like triangles and circles. Malpighi would have found nothing to object to in this passage and the attitude it represents, and in fact we have seen that he echoed it in the Risposta to Lipari. In his Risposta to Sbaraglia too he attacked the principle of authority. In both Risposte, however, his strategy was not so much to contrast textual authority with direct observation of nature, but rather to show that classical and modern sources did not undermine his own research. In this respect Malpighi's work sought reconciliation between ancient and modern traditions and did not eschew careful philological and hermeneutical analyses of the passages quoted by his opponent to show that Sbaraglia's interpretation was inaccurate and tendentious. This attitude was rather common in medical circles and was strikingly immortalized in some medals, notably that of John Freind, showing the portrait of the physician on one side and the personifications of medicina vetus et nova shaking hands on the other. ${ }^{29}$

\section{Therapy and the New Anatomy}

What was at stake in the dispute with Sbaraglia, however, was not so much a conceptual reinterpretation, but its significance to pathology and therapy. The bulk of Malpighi's Risposta sought to show that the anatomical findings of the seventeenth century had a significant impact not only on our understanding of the "animal oeconomy", but on the nature of disease and therapeutics as well, and that these aspects should not be separated. Malpighi often talked of the importance of combining the a priori method with that a posteriori. The a priori method was based on anatomical knowledge and reasoning about causes: for example, he believed that most organs consist of a series of glands that filter a certain fluid from blood, urine in the kidneys, bile in the liver, etc. Often disease consisted in the malfunctioning or obstructions of those glands; therefore the indicationes, or the therapeutic strategy based on the knowledge of the cause of the disease, consisted in removing those obstructions. We witness here the important role of anatomy for pathology as a key step towards a successful therapy. ${ }^{30}$

\footnotetext{
${ }^{27}$ Bertoloni Meli, 'Posthumous dispute', $M A P, \mathrm{p}$. 260.

${ }^{28}$ MOB, pp. 512, 514; Galluzzi, op. cit., note 25 above.

${ }^{29}$ GOF, vol. 6, p. 232 , par. 6 of the Assayer; $M O B$, p. 528. See also R J J Martin, 'Explaining John Freind's History of Physick', Stud. Hist. Philos. Sci., 1988, 19: 399-418.

${ }^{30}$ MOB, p. 536; Malpighi provides a definition of indicationes, a hallmark of rational medicine in ibid, $\mathrm{p}$.
}

564. Galen, On the therapeutic method. Books I and II, Oxford, Clarendon Press, 1991, pp. 63-4, and the commentary by R J Hankinson, pp. 202-6. Wear, op. cit., note 2 above, p. 305; F Kudlien and R J Durling (eds), Galen's method of healing, Brill, Leiden, 1991, deals extensively with the history and significance of this term from Galen to the Renaissance, see in particular the excellent J J Bylebyl paper, 'Teaching Methodus medendi in the Renaissance', pp. 157-89, especially pp. 174-88. 


\section{The Medical Assayer of Marcello Malpighi}

Malpighi argued forcefully that the moderns have reformed to some extent medical practice as a result of their anatomical investigations. Of course, he had often his own microscopic investigations in mind. He explained carefully and in detail how therapies of the liver, kidneys, eyes, and heart had been affected. Our sense of these changes of seventeenth-century therapeutics is quite vague; therefore Malpighi's account is of extraordinary interest for the light it sheds on this area. His description of the disease of the kidneys known as spurious diabetes, leading to excessive urination, is one of my favourites for the links it establishes between the new corpuscular philosophy, in whose history Galileo occupied a nodal position, and therapeutics. According to the ancients, this disease was due to the excessive heat of the kidneys, whereby they attract an immoderate amount of serum. Others also explained the disease by the existence of an acrid humour that impregnates the kidneys' flesh and enhances their expulsive faculty. "Faculty" was a technical term related either to the operations of the soul, as for Aristotle, or of nature but specific to living organisms, as for Galen; in any event it was a notion that mechanists like Malpighi wished to abolish altogether. The standard therapy in these cases was to use astringents and to cool the kidneys, abstaining from providing fluids. According to the Moderns, however-no prize given to guess whom Malpighi had in mind here-the kidneys are a collection of glands that filter blood because they have apertures similar to the particles of water present in the blood. By relying on reasoning inspired by new anatomical knowledge- a very speculative one in our eyes-Malpighi argued that empty spaces are intermixed with those water particles, and often salts are to be found in those spaces. Those salts that are reduced to minute parts by the fermentation occurring in the kidneys can form small wedges that open with some violence the apertures of the glands in the kidneys, leading to excessive urination. Hence the therapy derived a priori from the cognition of the causes of the disease is to administer fluid and watery remedies that can dilute those salty wedges so that they can be expelled without damaging the kidneys. What is especially interesting here is the explanation of disease in mechanistic terms, the key notions being no longer that of excessive heat and attraction but rather filtration and the shapes and motions of particles. In another instance Malpighi defended the microscope by using it directly to observe a layer appearing on the surface of urine. Traditionally that layer was thought to consist of fat, leading to a therapeutic strategy. But the microscope showed it to be an aggregate of sandy particles, which changed the therapy. ${ }^{31}$

While Malpighi could claim that his anatomical investigations with the microscope had revealed the microstructure of several organs and therefore provided the physician with a new understanding of pathology and indirectly crucial knowledge on therapy, the case of the layer of fat on the surface of urine appears to have been unique as a direct application of microscopy to therapeutics. It was this hiatus between anatomical knowledge and therapeutic practices that was at the centre of Sbaraglia's concerns. It is not clear which were his sources at this stage; in Oculorum et mentis vigiliae he referred to Thomas Sydenham, for example, but his name did not appear in the earlier attack on Malpighi, though Malpighi did mention Sydenham in his reply. ${ }^{32}$

\footnotetext{
${ }^{31}$ Malpighi's De renibus was published as part of De viscerum structura, Bologna, ex typographia Jacobi Montii, 1666. On this work, see D Bertoloni Meli, 'Blood, monsters, and necessity in Malpighi's De polypo cordis', Med. Hist., 2001, 45:
} 


\section{Domenico Bertoloni Meli}

Malpighi's remedies and those advocated by mechanistic anatomy generally were not new, but relied on traditional ingredients such as ground millipedes, human urine, and ground human skull, a collection of ingredients that has recently been misleadingly compared to the potions of Macbeth's witches. At times those remedies were administered in different circumstances from what tradition recommended. In the case of ophthalmia, for example, the traditional remedy involved venesection in the vicinity of the eye. However, since blood circulates, in the Risposta to Sbaraglia Malpighi argued that it made no sense to remove blood from one area of the body. Rather, the excess of blood in that area was attributed to a local impediment of acid salts that had to be removed. Sbaraglia accepted Harvey's finding of the circulation of the blood, but argued that even this major discovery had brought no new therapies. In his reply Malpighi could point out that new anatomical findings about the heart and arteries had enriched the knowledge of pathology; moreover, traditionally, bloodletting was banned in the case of cardiac syncope, whereas he noticed approvingly that in his time bloodletting was performed in those cases. Despite Malpighi's optimism, there was a sense of uncertainty in the neoteric camp concerning bloodletting, for example. In an important letter of 1667 to Malpighi, the physician Giovanni Battista Capucci from Crotone stated that Tommaso Cornelio at Naples was opposed to venesection, whereas he himself adopted it more for convenience than for conviction. Chinese doctors, however, according to Daniello Bartoli, laughed at this European practice. With regard to the lungs too, Malpighi provided an account of recent anatomical findings leading to a new conception of disease and therapeutic strategy. Malpighi attributed many lung diseases to the sluggishness of the blood in the small capillaries of the lungs and thought of counteracting it with volatile spirits of hartshorn and human blood, for example. The understanding of asthma too had been transformed, with the distinction between dry and humid. Therapies for both forms were transformed in the second half of the century as a direct result of new anatomical findings. Often, even in those cases when the remedy was both entirely traditional and applied in traditional circumstances, Malpighi and his fellow mechanists provided a different rationale for its application. ${ }^{33}$

To sum up, the issue can be best addressed by adopting a fourfold partition involving pathology or the rational understanding of the causes and locations of diseases, the rationale for the cure, the pharmacopoeia, and the circumstances of application of specific procedures and medicamenta. Generally the pathological understanding of the disease and the rationale for the therapy provided by mechanistic anatomists were very different from traditional ones. While mechanistic anatomy did not alter the available pharmacopoeia, at times the circumstances of application of entirely traditional procedures and medicamenta did change, however; therefore standard remedies and procedures like venesection were prescribed-or avoided - in circumstances different from traditional ones.

\section{Reading Malpighi's Risposta to Sbaraglia}

Malpighi's adoption of the Assayer as a malleable template for his Risposta to Sbaraglia raises some questions on Malpighi's agenda and on how contemporaries may have read his

\footnotetext{
${ }^{33} M O B$, pp. 560, 562-3, 565-6. For the reference to Macbeth's witches, see Piccolino, op. cit., note 6 above, p. 159. Compare the usage of milk for curing fevers, discussed in Bertoloni Meli, 'The new
}

anatomy', $M A P$, pp. 34-5. MCA, vol. 1, pp. 336-41, Capucci to Malpighi, 21 Jan. 1667, on pp. 337-8 and nn.17-18. See also D Bertoloni Meli, 'Francesco Redi e Marcello Malpighi', op. cit., note 2 above. 
work. One could argue that Malpighi was caught in a dispute and found inspiration in the Assayer, with no further implications. We may wonder who at the time would have been able to appreciate Malpighi's literary strategy, since Borelli, the person best placed to grasp his rhetorical moves, had been dead for years. In the preface to the Amsterdam 1698 edition of Malpighi's Opera posthuma, the Calvinist expatriate Pierre Régis stated that despite Malpighi's international fame, at home he had been subjected to vicious criticisms and attacks, and compared him in this regard to Harvey, Gassendi, Descartes, and especially Galileo. Régis added that Malpighi's findings were universally accepted, except for those areas at the periphery of Europe still lying in darkness. Thus in this regard it appears that Malpighi's move had been successful in that Régis openly sided with him. It is unclear, however, to what extent scholars and physicians in about 1700, in Italy and especially abroad, would have been familiar with the Assayer. We are unsure as to how widespread knowledge of Galileo's work would have been even among Malpighi's own disciples. Although the Assayer is considered one of Galileo's literary masterpieces, it was not translated and therefore its readership outside Italy was limited. By contrast, the Dialogo received an early Latin translation that was often reprinted, making Galileo's work available to a European readership. I believe that Sbaraglia did appreciate Malpighi's rhetorical and philosophical moves, at least in part, even if he may not have realized their literary source. In his reply he attacked Galileo's Dialogue, questioned the accuracy of the microscope, and referred to debates and controversies following Galileo's introduction of the telescope, in order to show that these new instruments ought to be handled with caution. ${ }^{34}$

In Italy there were other scholars and readers in the know, besides Borelli, likely to be on Malpighi's agenda. Francesco Redi, personal physician to several Medici Grand Dukes, was almost certainly among them, given his profound medical and literary interests. Redi was well acquainted with Malpighi as well as with intellectual affairs at the Tuscan court and with Galileo's writings. ${ }^{35}$ Although Redi outlived Malpighi, he died in 1697, the same year that Malpighi's Risposta saw the light. Lorenzo Bellini (d. 1704), professor of anatomy at Pisa University and member of the literary Crusca Academy, had been Borelli's disciple and close ally from the 1660s and was likely to be familiar with his views and recommendations as much as Malpighi. Vincenzo Viviani (d. 1703) was another intellectual at the Tuscan court worthy of our attention. Viviani was a mathematician and member of the Cimento Academy who portrayed himself as Galileo's last disciple. In this capacity, he saw himself as the promoter and defender of Galileo's tradition. In an important exchange of 1693, Viviani reported worrying news from clerical circles in Rome. He quoted a passage from a letter by the Florentine Jesuit Antonio Baldigiani, without mentioning his name, according to whom the Church was becoming increasingly hostile to "mathematicians and physico-mathematicians", notably Galileo, Gassendi, and Descartes, and was preparing long lists of authors to be banned. Baldigiani was professor of

\footnotetext{
${ }^{34}$ Sbaraglia, op. cit., note 12 above, second part, pp. 615ff. The Assayer was included in the 1655 Bologna and 1718 Florence editions of Galileo's works. Cavazza, op. cit., note 16 above, p.129; A M Vidal, J P Tomás, 'In tenebris adhuc versantes: la respuesta de los novatores españoles a la invectiva de Pierre Régis', Dynamis, 1995, 15: 301-40; M Cavazza, Settecento
}

inquieto, Bologna, Il Mulino, 1990, pp. 101-4 and ch. 5 .

${ }^{35}$ Bernardi and Guerrini (eds), op. cit., note 2 above. In addition to the correspondence in $M C A$, several letters between Redi and Malpighi are published in D Bertoloni Meli, 'Additions to the correspondence of Marcello Malpighi’, MAP, pp. 279-312. 


\section{Domenico Bertoloni Meli}

mathematics at the Collegio Romano and member of the Congregation of the Index. Those exchanges were occurring about the same time as the trial against some atomist philosophers in Naples and when Cosimo III banned atomism at Pisa University and ordered that only Aristotelian philosophy should be taught. ${ }^{36}$ In his reply, Malpighi, who at the time was pontifical archiater at Rome, claimed that he had "no precise information", but knew that the issue had been going on for some time. He also expressed the hope that the matter would subside, because there were learned cardinals among the members of the Congregation of the Index. ${ }^{37}$ Thus it appears that Malpighi was aware that the new philosophy and Galileo were under attack from clerical circles, especially with regard to atomism.

Malpighi's choice of modelling the Risposta to Sbaraglia on the Assayer did not lack peculiar features. Galileo had died in 1642 under house arrest following his condemnation for vehement suspicion of heresy by the Inquisition, and the new philosophy he had so prominently promoted was being challenged in late seventeenth-century Rome. It was remarkable that the pontifical archiater would choose as a model one of Galileo's texts, especially one defending atomism as the Assayer. His move was noteworthy in other respects as well. In choosing a literary and philosophical model for his work, Malpighi was also reminding his readers of who the Galileo of medicine was, the scholar who had transformed anatomy by means of the microscope much as Galileo had transformed astronomy by means of the telescope, and who had been subjected to endless vexations. These may have been additional motives why Malpighi wanted this work to appear posthumously. This example shows that styles of writing are not just a matter for literary historians, but can be crucial in reconstructing and identifying a text's intellectual horizons and philosophical contents relevant to traditional history of medicine, science, and philosophy. In conclusion, Malpighi probably had different intended audiences for his Risposta, which was published in London both in Italian and Latin: readers with medical and philosophical interests would have followed the text without any problem, but those readers familiar with Galileo's legacy and the Assayer, most likely in Italy, would have been able to decode an additional dimension of the text that would have been unnoticed by others.

The identification of the Assayer as the template for Malpighi's work is both pleasing and troubling at the same time. Looking at Malpighi's style of writing has enriched our reading of one of the most revealing medical texts at the end of the seventeenth century, but it also makes one wonder whether obvious sources elsewhere have not been identified. While working on a period when authors often had recourse to hidden quotations and coded messages and when literary style was chosen with care, it may be appropriate to have such worries.

\footnotetext{
${ }^{36}$ Relevant material can be found in Lomonaco and Torrini (eds), op. cit., note 25 above; V Ferrone, Scienza natura religione: mondo newtoniano e cultura italiana nel primo Settecento, Napoli, Jovene, 1982, pp. 3-11; Ferrone's book offers an intellectual profile of the Italian scene in the eighteenth century. M Torrini,
}

Dopo Galileo. Una polemica scientifica, 1684-1711, Florence, Olschki, 1979, p. 28.

${ }^{37}$ See the letters published by C Dollo, 'Inediti per l'epistolario malpighiano', Rivista di Storia della Filosofia, 1984, 3: 537-50. Malpighi's letter is dated from Rome, 7 Feb. 1693. 